\title{
PENILAIAN TINGKAT KEBAHAGIAAN MASYARAKAT KAMPUNG KOTA (STUDI KASUS KAWASAN PERMUKIMAN KAMPUNG BRAGA BANDUNG)
}

\author{
Measuring Happines Index in Kampung Kota \\ (Case Study of Settlement Area in Kampung Braga Bandung)
}

Sally Indah Nurdyawati ${ }^{1}$, Holi Bina Wijaya ${ }^{1}$

Diterima: 25 Desember 2017

Disetujui: 8 Agustus 2018

\begin{abstract}
Abstrak: Pengukuran indeks kebahagiaan di Indonesia dilakukan oleh Badan Pusat Statistik (BPS) dan dirilis pertama kali pada tahun 2013 berdasarkan hasil studi dan representasi estimasi tingkat nasional. Pendekatan yang dilakukan berupa pendekatan kepuasan hidup, di mana kepuasan hidup dipercaya dapat merefleksikan tingkat kebahagiaan. Kota Bandung merupakan salah satu kota yang menginisiasi studi pengukuran indeks kebahagiaan di Indonesia. Kampung Braga merupakan salah satu kampung kota yang masih mempertahankan eksistensinya di tengah desakan pembangunan kota. Lingkungan permukiman Kampung Braga dinilai kumuh dan bangunan di dalamnya melanggar garis sempadan sungai. Berdasarkan hal tersebut maka timbul pertanyaan bahwa "Seberapa besar tingkat kebahagiaan masyarakat Kampung Braga?". Variabel yang digunakan terdiri dari variabel kebahagiaan dan keruangan. Analisis yang digunakan meliputi deskriptif kuantitatif dengan menggunakan pembobotan dan skoring pada masing-masing variabel. Berdasarkan hasil analisis, indeks kebahagiaan masyarakat Kampung Braga mencapai 0,978 yang artinya termasuk ke dalam kategori sangat bahagia. Pada proses pembentukan kebahagiaan, kontribusi komponen afektif relatif imbang dengan kognitif. Secara spasial, masyarakat RW 04 dan RW 08 cenderung lebih bahagia. Penelitian ini membuktikan bahwa masyarakat Kampung Braga memiliki kemampuan adaptasi dengan lingkungan perkotaan.
\end{abstract}

Keyword in Bahasa: indeks kebahagiaan, kampung kota, kampung braga

\begin{abstract}
The measurement of happiness index in Indonesia was conducted by Badan Pusat Statistik (BPS) was first released in 2013 based on the result of study and representation of national level estimation. The approach taken is a life satisfaction, in which life satisfaction is believed to reflect the level of happiness. The city of Bandung is one of the cities that initiated the measurement of happiness index in Indonesia. Kampung Braga is one of Kampung Kota that still maintain its existence in the middle of the urban development. The neighborhood of Kampung Braga is considered as slum area and the buildings within break the river border line. According to than phenomena, the research question comes up, "How big is the level of happiness Kampung Braga neighborhood?". Variables used ini this research consist of happiness and spatial variables. The analysis used is descriptive quantitative by weighting and scoring on each variable. Based on the results, the happiness index of Kampung Braga neighborhood is 0.978 which belongs to the category of very happy. In forming proccess of happiness, the affective component contribution is relatively balanced with the cognitive. Spatially, people in RW 04 and RW 08 tend to be happier. This study proves that the people of Kampung Braga have the ability to adapt to the urban environment.
\end{abstract}

Keywords: happiness index, kampung kota, kampung braga

1 Departemen Perencanaan Wilayah dan Kota, Fakultas Teknik, Universitas Diponegoro

Korespondensi: sallyindahn@gmail.com 


\section{PENDAHULUAN}

Istilah kebahagiaan dalam ilmu sosial sains seringkali merupakan cerminan dari kondisi yang ideal, yang ditunjukkan oleh kepuasan terhadap hidup secara keseluruhan. Studi pengukuran tingkat kebahagiaan telah dilakukan oleh banyak peneliti di berbegai negara. Salah satunya yang diutarakan mengenai konsep kebahagiaan oleh Veenhoven (1984) bahwa komponen utama dari kebahagiaan, yaitu komponen afektif (hedonic level of affect) dan kognitif (contentment). Hedonic level of affect merupakan tingkatan di mana pengalaman menyenangkan mempengaruhi kehidupan seseorang. Sedangkan contentment merupakan komponen kognitif yang mencerminkan tingkatan di mana yang didapatkan oleh individu bertemu dengan aspirasinya. Menurut Layard (2005) dalam (Goldberg, Leyden, \& Scotto, 2012), terdapat beberapa faktor yang mempengaruhi kebahagiaan seseorang, yaitu pendapatan atau kondisi finansial, hubungan keluarga, persepsi terhadap pekerjaan, hubungan sosial terhadap komunitas, dan kesehatan.

Studi lain menunjukkan bahwa tingkat kebahagiaan perempuan lebih tinggi dari lakilaki (Stutzer \& Frey, 2006). Adanya hubungan positif antara umur dan kebahagiaan (Mroczek \& Kolarz, 1998). Hubungan antara pendidikan dan kebahagiaan umunya positif, semakin tinggi tingkat pendidikan seseorang, maka semakin tinggi pula tingkat kebahagiaannya (Lyubomirsky, King, \& Diener, 2005). Aspek pendapatan dengan kebahagiaan menunjukkan hubungan yang positif. Seseorang dengan pendapatan tinggi akan memiliki tingkat kebahagiaan yang tinggi pula. Pendapatan tidak secara signifikan mempengaruhi tingkat kebahagiaan (Pankaj \& Dorji, 2012). Namun, studi lain membuktikan bahwa hubungan antara pendapatan dan kebahagiaan cenderung positif, tetapi tidak signifikan (Leyden, Goldberg, \& Michelbach, 2011). Pendapatan tentunya erat hubungannya dengan pekerjaan. Seseorang yang memiliki pekerjaan tetap cenderung lebih bahagia dibandingkan mereka yang memiliki pekerjaan yang tidak tetap.

Badan Pusat Statistik Indonesia telah melakukan Survei Pengukuran Tingkat Kebahagiaan (SPTK) sejak tahun 2013. Salah satu kota yang juga melakukan SPTK adalah Kota Bandung. Berdasarkan data yang didapat dari Badan Pusat Statistik Kota Bandung, indeks kebahagiaan masyarakat Kota Bandung pada tahun 2016 mencapai 73,27 dari skala 1-100. Survei tersebut dilakukan secara general yang mencakup berbagai golongan masyarakat. Di sisi lain, Kota Bandung juga tidak dapat dilepaskan dari fenomena kemiskinan yang pada tahun 2015 sebanyak 8\% dari total penduduk Kota Bandung masih tergolong ke dalam masyarakat miskin. Masyarakat yang termasuk ke dalam golongan ini bisanya bertempat tinggal pada ruang-ruang sempit di kota, salah satunya adalah kampung kota.

Salah satu kampung kota yang masih menunjukkan eksistensinya di tengah desakan pembangunan Kota Bandung adalah Kampung Braga. Meskipun kondisi lingkungan sekitarnya telah beralih fungsi menjadi kawasan perdagangan dan jasa, masyarakat Kampung Braga lebih memilih bertahan dan tinggal tempat semula, yakni di bantaran Sungai Cikapundung. Berdasarkan fenomena tersebut maka muncul pertanyaan "Seberapa besar tingkat kebahagiaan masyarakat Kampung Braga?”. Tujuan dari penelitian ini adalah untuk mengukur tingkat kebahagiaan masyarakat Kampung Braga dalam menjalani kehidupannya dikaitkan dengan kondisi fisik ruang kawasan.

\section{METODE PENELITIAN}

Metode yang digunakan dalam penelitian ini adalah deskriptif kuantitatif dengan pembobotan dan skoring sebagai metode anaisisnya. Variabel yang digunakan dalam penelitian terbagi ke dalam dua kelompok, yaitu variabel kebahagiaan serta variabel keruangan. Variabel kebahagiaan meliputi kesehatan, pendidikan, pemerintahan, peran 
komunitas dan keluarga, dan standar hidup. Sedangkan variabel keruangan meliputi hunian, sarana prasarana, dan lingkungan. Alur analisis yang digunakan meliputi identifikasi kondisi kebahagiaan, identifikasi kondisi fisik ruang, pengukuran tingkat kebahagiaan, serta kajian implikasi terhadap pembangunan Kota Bandung.

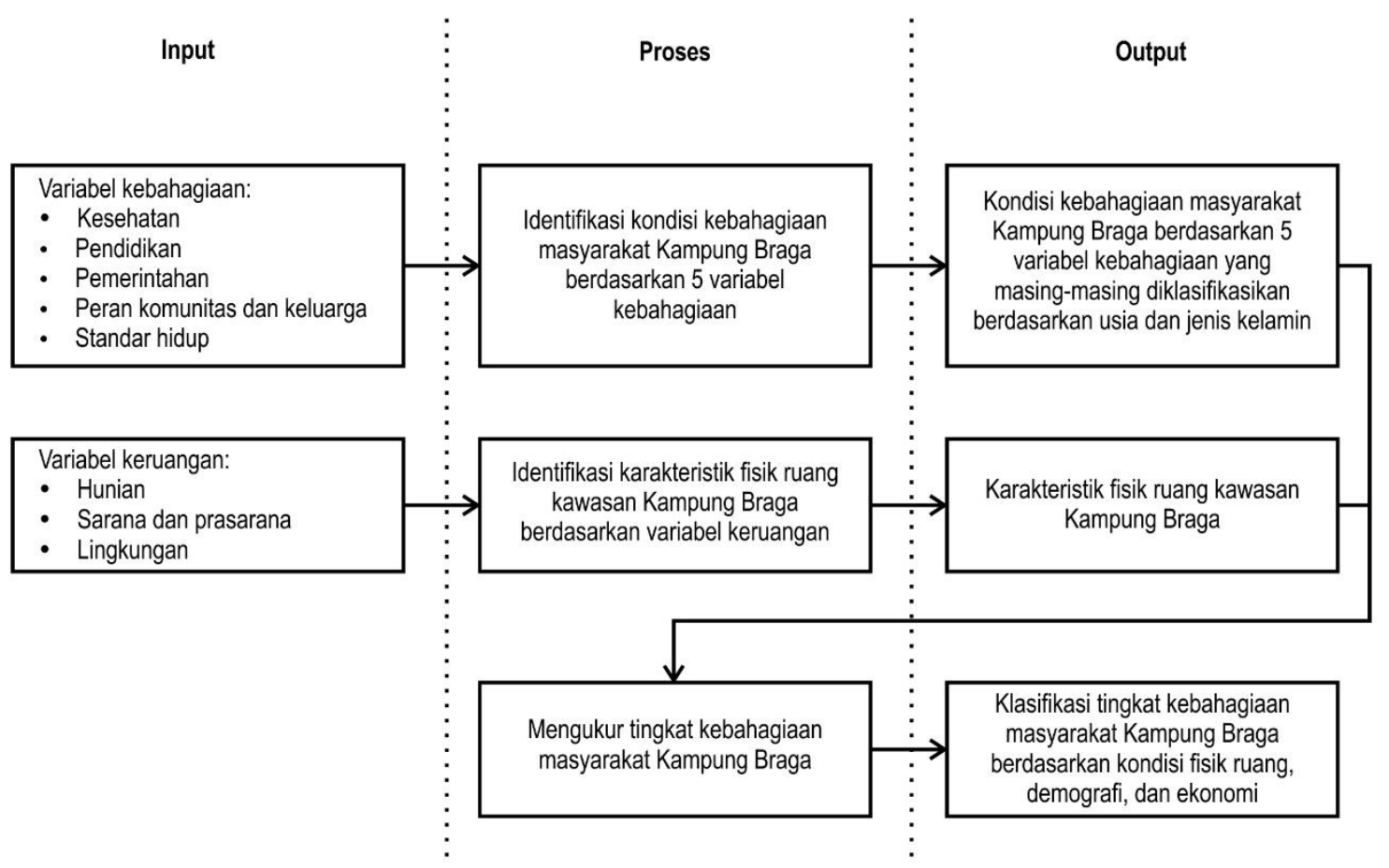

\section{Gambar 1. Kerangka Analisis Penelitian}

Metode skoring dan pembobotan diakukan pada 16 indikator kebahagiaan. Penentuan bobot diambil melalui literatur yang ada seperti yang terlihat pada Tabel 1. Pembobotan terhadap 19 indikator tersebut akan menghasilkan output berupa klasifikasi 'bahagia' ke dalam 4 kriteria, yaitu unhappy, narrowly happy, extensively happy, dan deeply happy.

Tabel 1. Pembobotan Indikator Penelitian

\begin{tabular}{lcc}
\hline Indikator & Bobot & Sumber \\
\hline Variabel Kesehatan & & \\
Kepuasan terhadap kondisi kesehatan & $10 \%$ & \\
Hari sehat & $8 \%$ & (Dwi et al., 2016) \\
Angka harapan hidup & $2 \%$ & \\
Variabel Pendidikan & & \\
Kemampuan menulis dan membaca & $7 \%$ & \\
Tingkat pendidikan & $7 \%$ & (Dwi et al., 2016) \\
Pengetahuan & $5 \%$ & \\
Variabel Pemerintahan & & \\
Kinerja pemerintah & $3 \%$ & (Dwi et al., 2016) \\
Partisipasi politik & $9 \%$ &
\end{tabular}




\begin{tabular}{lcc}
\hline Indikator & Bobot & Sumber \\
\hline Variabel Kesehatan & & \\
Pelayanan & $9 \%$ & \\
Variabel Peran Komunitas dan Keluarga & & \\
Hubungan sosial & $6 \%$ & \\
Keluarga & $6 \%$ & (Dwi et al., 2016) \\
Keamanan & $8 \%$ & \\
Variabel Standar Hidup & & \\
Pendapatan & $6 \%$ & \\
Pekerjaan & $2 \%$ & GNHI \\
Aset & $6 \%$ & \\
Perumahan & $6 \%$ & \\
\hline
\end{tabular}

Sumber: Hasil Analisis, 2017

Tabel 2. Klasifikasi Tingkat Kebahagiaan

\begin{tabular}{clc}
\hline Presentase & \multicolumn{2}{c}{ Klasifikasi Tingkat Kebahagiaan } \\
\hline$<50 \%$ & Unhappy & \multirow{2}{*}{ Not-yet-happy } \\
$50 \%-65 \%$ & Narrowly happy & \\
$66 \%-76 \%$ & Exsentively happy & Happy \\
$>77 \%$ & Deeply happy & \\
\hline
\end{tabular}

Sumber: Gross National Happiness Index, 2012

\section{HASIL DAN PEMBAHASAN}

Berdasarkan hasil analisis, maka didapatkan nilai indeks kebahagiaan sebesar 0,978 yang artinya bahwa masyarakat Kampung Braga termasuk ke dalam kategori sangat bahagia. Hal tersebut sejalan dengan Studi Pengukuran Tingkat Kebahagiaan (SPTK) oleh pemerintah kota, di mana hasilnya menunjukkan bahwa masyarakat Kota Bandung termasuk ke dalam kategori sangat bahagia. Presentase yang termasuk ke dalam kategori happy sebanyak $96 \%$, sedangkan kategori not-yet-happy hanya 4\%. Di antara 4\% masyarakat tersebut yang termasuk ke dalam kategori not-yet-happy, ternyata rata-rata dari mereka hanya menikmati $52 \%$ kepuasan dalam hidupnya. Secara keseluruhan, pembentukan kebahagiaan masyarakat Kampung Braga didominasi oleh komponen kognitif (53,31\%) dibandingkan komponen afektif $(46,67 \%)$.

Tabel 3. Klasifikasi Tingkat Kebahagiaan Masyarakat Kampung Braga

\begin{tabular}{|c|c|c|c|}
\hline & & Presentase Populasi & $\begin{array}{l}\text { Rata-rata kepuasan } \\
\text { terhadap variabel }\end{array}$ \\
\hline \multirow{2}{*}{$\begin{array}{l}\text { Not-yet-happy } \\
\text { People }\end{array}$} & Unhappy & $2 \%$ & $43 \%$ \\
\hline & Narrowly Happy & $2 \%$ & $61 \%$ \\
\hline \multirow{2}{*}{ Happy People } & Extensively Happy & $8 \%$ & $73 \%$ \\
\hline & Deeply Happy & $88 \%$ & $87 \%$ \\
\hline
\end{tabular}

Sumber: Hasil Analisis, 2017 


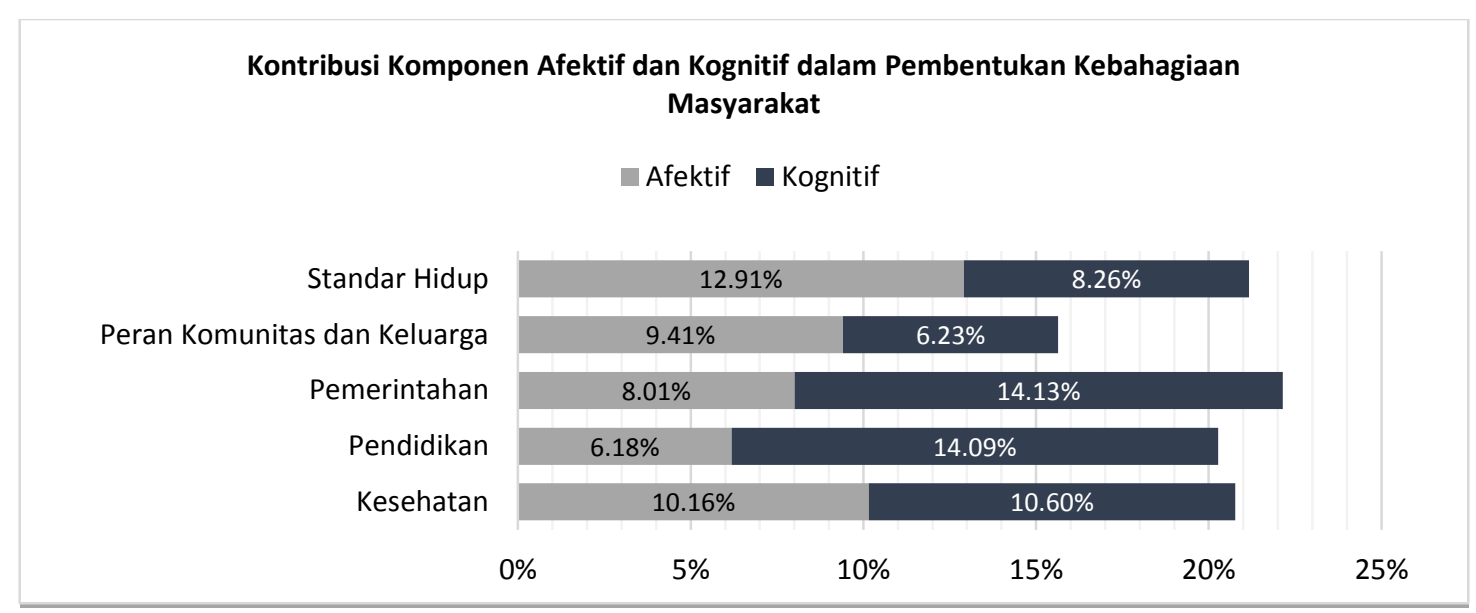

Sumber: Hasil Analisis, 2017

\section{Gambar 2. Kontribusi Komponen Afektif dan Kognitif dalam Pembentukan Kebahagiaan Masyarakat}

Komponen kognitif memiliki kontribusi yang lebih besar pada variabel kesehatan, pendidikan, dan pemerintahan. Sedangkan komponen afektif mendominasi pada variabel peran komunitas dan keluarga serta standar hidup. Pada variabel kesehatan, peran dari kedua komponen relatif imbang. Dengan kata lain, kepuasan masyarakat terhadap kondisi kesehatan baik secara subjektif ataupun objektif cukup tinggi. Sejalan dengan Stutzer dan Frey (2006) bahwa penilaian kesehatan secara subjektif memiliki efek yang lebih signifikan terhadap kebahagiaan dibandingkan dengan penialaian objektif secara medis. Hal tersebut dibuktikan dengan fakta pada analisis sebelumnya bahwa sebanyak $92 \%$ masyarakat puas dengan kondisi kesehatannya. Berbeda dengan kesehatan, pada variabel standar hidup justru komponen afektif lebih mendominasi daripada komponen kognitif. Hal tersebut menggambarkan bahwa meskipun secara objektif Kampung Braga merupakan kawasan yang kumuh (Wihadanto et al., 2017) dan mayoritas pendapatannya berada di bawah UMR, tetapi memiliki tingkat afektif yang tinggi. Fenomena tersebut yang biasa dikenal sebagai 'konsep bersyukur' atau sebagaimana diutarakan oleh Zapf (dalam Veenhoven, 2006) sebagai kemampuan adaptasi. Adanya 'konsep bersyukur' ini membuat kesenjangan antara kondisi eksisting dengan kondisi ideal yang sebelumnya tinggi, menjadi terlihat lebih sempit.

Variabel yang paling berpengaruh dalam pembentukan kebahagiaan masyarakat Kampung Braga adalah Pemerintahan. Hal tersebut didukung dengan fakta pada analisis sebelumnya bahwa sebanyak $68 \%$ masyarakat merasa puas dengan kinerja pemerintah setempat, baik dari aspek transparansi, pelayanan, dan partisipasi politik. Hasil temuan studi tersebut tidak relevan dengan SPTK Kota Bandung, di mana variabel utama pembentuk kebahagiaan masyarakat Kota Bandung adalah aspek Perumahan. Perbedaan tersebut kemungkinan dapat terjadi karena lokasi serta karakteristik masyarakat yang diteliti. Masyarakat Kampung Braga memiliki keunikan tersendiri dibandingkan masyarakat Kota Bandung pada umumnya. 


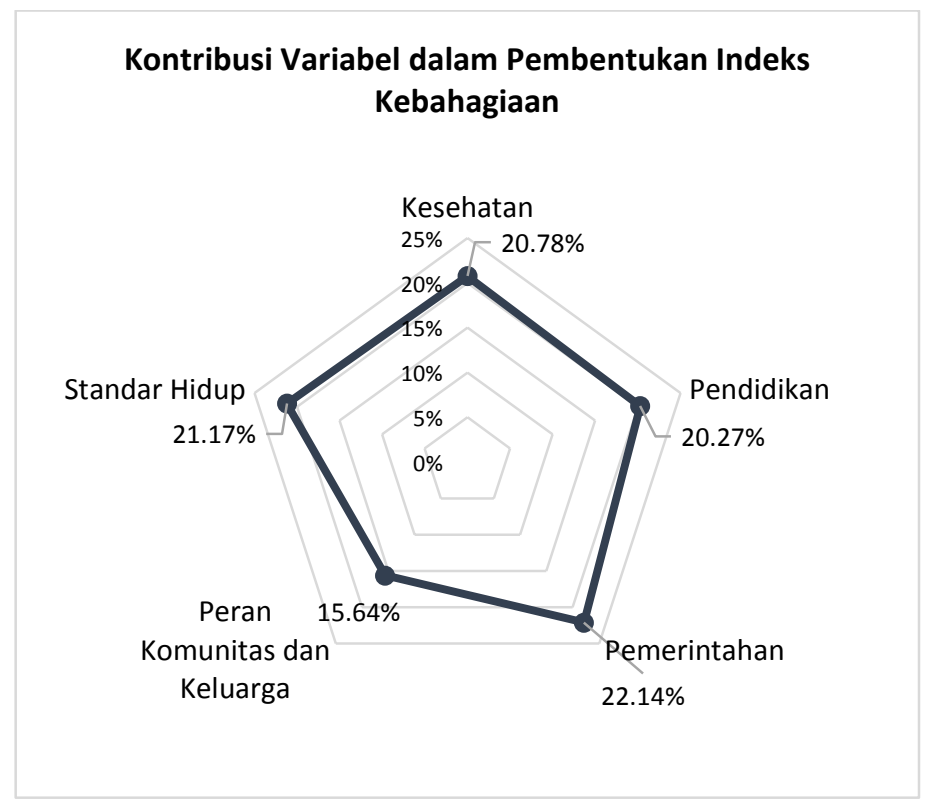

Sumber: Hasil Analisis, 2017

Gambar 3. Kontribusi Variabel dalam Pembentukan Indeks Kebahagiaan

Tabel 4. Karakteristik Happy People dan Not-yet-happy People

\begin{tabular}{|c|c|c|c|}
\hline \multicolumn{2}{|c|}{ Aspek } & Happy People & Not-yet-happy People \\
\hline \multicolumn{2}{|c|}{ Kondisi fisik ruang } & $\begin{array}{l}\text { Berada pada tipologi kawasan (A) } \\
\text { dengan karakteristik: } \\
\text { - Berada di sepanjang sempadan } \\
\text { sungai } \\
\text { - Akses jalan sempit, berada pada } \\
\text { gang dengan lebar jalan } 1-1,5 \mathrm{~m} \\
\text { - Tata letak bangunan tidak } \\
\text { berarturan } \\
\text { - Tampilan bangunan sederhana } \\
\text { - Material bangunan permanen dan } \\
\text { semi permanen } \\
\text { - Luas bangunan } 10-20 \mathrm{~m}^{2} \\
\text { - Fungsi bangunan hunian } \\
\text { - Mayoritas merupakan penduduk } \\
\text { lokal }\end{array}$ & $\begin{array}{l}\text { Berada pada tipologi kawasan (B) } \\
\text { dengan karakteristik: } \\
\text { - Berada di lokasi yang aksesibel } \\
\text { - Akses jalan relatif mudah, lebar jalan } \\
3-4 \mathrm{~m} \\
\text { - Tata letak bangunan relatif teratur } \\
\text { - Tampilan bangunan modern } \\
\text { - Material bangunan permanen } \\
\text { - Luas bangunan rata-rata }>20 \mathrm{~m}^{2} \\
\text { - Fungsi bangunan hunian dan kost } \\
\text { - Mayoritas merupakan pendatang }\end{array}$ \\
\hline \multirow[t]{2}{*}{ Demografi } & $\begin{array}{l}\text { Jenis } \\
\text { kelamin } \\
\text { Kelompok } \\
\text { umur }\end{array}$ & Mayoritas $>44$ tahun & Mayoritas perempuan \\
\hline & Pendidikan & $\begin{array}{l}\text { Berada pada berbagai jenjang } \\
\text { pendidikan }\end{array}$ & $\begin{array}{l}\text { Berada pada jenjang pendidikan SMA } \\
\text { dan Diploma }\end{array}$ \\
\hline \multirow{2}{*}{ Ekonomi } & Pekerjaan & Mayoritas pedagang & $\begin{array}{l}\text { Mayoritas ibu rumah tangga dan } \\
\text { lainnya (PNS, wiraswasta, dll) }\end{array}$ \\
\hline & Pendapatan & $\begin{array}{l}\text { Berada di atas UMR Kota Bandung, } \\
\text { lebih tepatnya }>2.500 .000\end{array}$ & $\begin{array}{l}\text { Berada di bawah UMR Kota Bandung, } \\
\text { lebih tepatnya }<2.500 .000\end{array}$ \\
\hline
\end{tabular}

Sumber: Hasil Analisis, 2017 


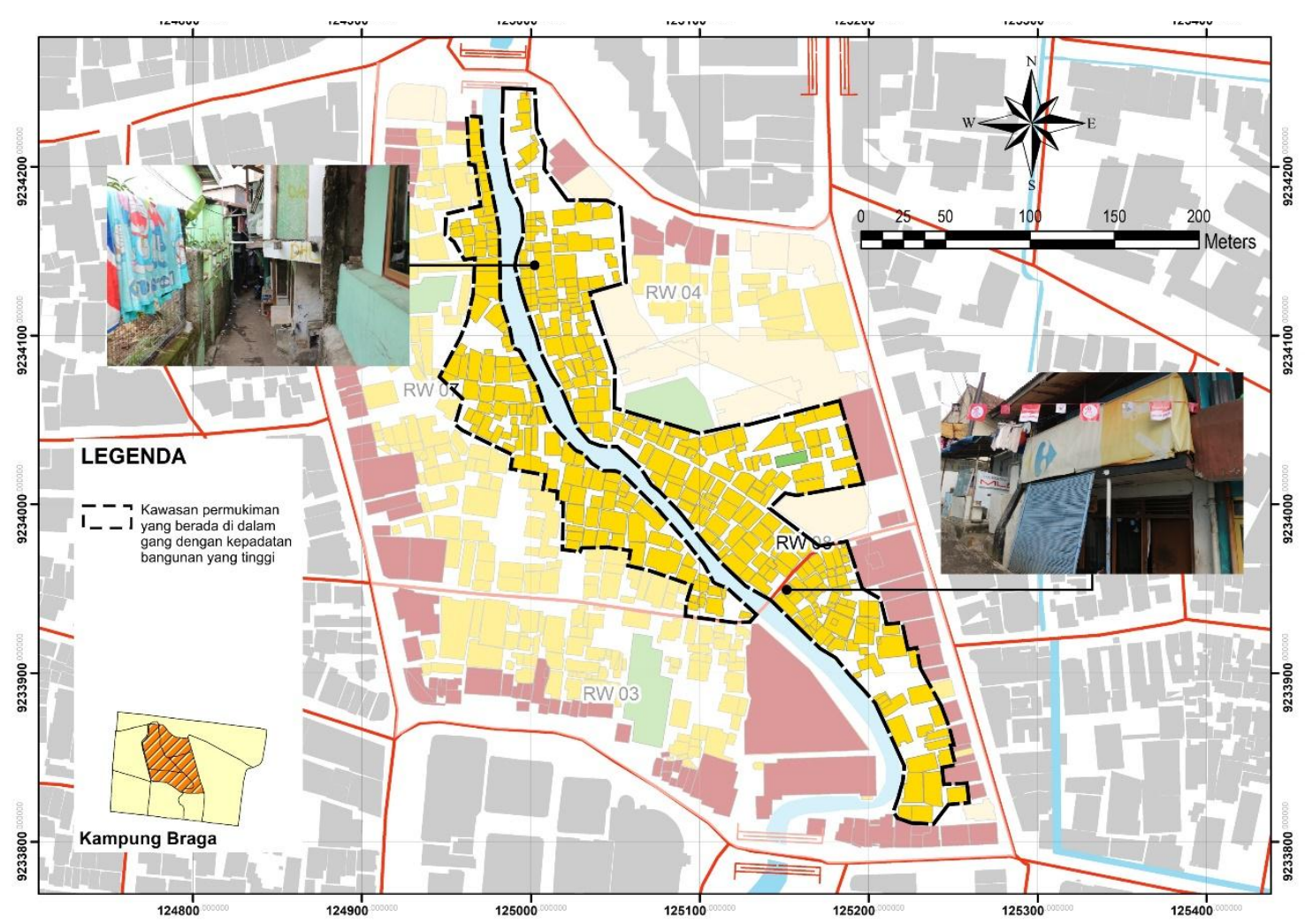

Sumber: Hasil Analisis, 2017

\section{Gambar 4. Tipologi Kawasan Permukiman Kumuh Kampung Braga}

Kriteria masyarakat yang termasuk ke dalam kategori happy people dan not-yet-happy people yang dikategorikan berdasarkan aspek kondisi fisik ruang kawasan, demografi, dan ekonomi. Temuan ini disajikan secara rinci pada Tabel 4. Pembentukan kebahagiaan masyarakat Kampung Braga pada dasarnya dibentuk oleh komponen afektif dan kognitif (lihat Gambar 5). Pada komponen afektif, proses pembentukan kebahagiaan didasari oleh karakteristik masyarakat. Hal tersebut membentuk suatu kebutuhan hidup, di mana pada kasus ini kebutuhan hidup masyarakat terbatas pada pedapatan yang diperoleh. Mengingat kondisi ekonomi masyarakat lokal cenderung rendah dan peran keluarga yang kuat, maka pengalaman afektif cenderung diperoleh dari interaksi sosial di lingkungan keluarga dan komunitas. Adanya pengalaman afektif yang relatif tinggi membuat tingkat hedonic level of affect pun tinggi.

Pada komponen kognitif, proses didasari oleh pembentukan norma dan budaya masyarakat lokal yang masih relatif terjaga. Norma dan budaya tidak muncul begitu saja, tetapi dipengaruhi oleh karakteristik dari masyarakat itu sendiri, proses tersebut disimbolkan dengan panah nomor (6). Norma dan budaya yang ada kemudian membentuk standar hidup masyarakat lokal yang pada umumnya lebih rendah dari pada standar hidup masyarakat perkotaan lainnya. Pembentukan standar hidup tersebut juga dipengaruhi dari komponen afektif. Panah nomor (5) menujukkan adanya pengaruh kuat dari kebutuhan hidup terhadap pembentukan standar hidup. Kebutuhan dan kemampuan masyarakat lokal dalam memenuhi hidupnya relatif rendah, mengingat terbatasnya kemampuan ekonomi. Oleh karena itu, masyarakat lokal cenderung menurunkan standar hidup (aspirasi hidup) mereka dari masyarakat perkotaan pada umumnya. 
Setelah terjadi penetapan standar hidup, maka berlangsung proses komparasi antar individu. Pada kasus ini, proses komparasi terdiri dari komparasi internal antar individu di Kampung Braga dan komparasi eksternal antara individu di lingkup Kampung Braga dengan masyarakat perkotaan pada umumnya. Pada proses komparasi internal, masyarakat cenderung membandingkan standar hidup dan realita satu sama lain di Kampung Braga, di mana karakteristik masyarakat lokal cenderung homogen sehingga nilai perbandingan antar individu relatif kecil. Namun, apabila komparasi dilakukan secara eksternal, maka hasil perbandingan yang didapatkan akan cenderung lebih besar. Proses komparasi dan pengalaman afektif pada dasarnya saling mempengaruhi (Veenhoven, 2006). Namun, pada kasus ini proses komparasi cenderung tidak mempengaruhi pengalaman afektif, dengan kata lain proses arah panah nomor (4) tidak terjadi. Proses tersebut hanya terjadi apabila standar hidup (aspirasi hidup) dapat melebihi kebutuhan hidup, tetapi hasil penelitian menunjukkan bahwa realita yang ada di Kampung Braga jauh dari kata ideal dan mayoritas berada di bawah standar sehingga hal tersebut tidak dapat menimbulkan pengalaman afektif bagi masyarakat lokal. Adanya proses komparasi tersebut menimbulkan kesenjangan antara realitas dan kondisi idel yang diinginkan. Fenomena tersebutlah yang dinamakan contentment. Sayangnya, gap atau kesenjangan antara realitas dan standar relatif tinggi.

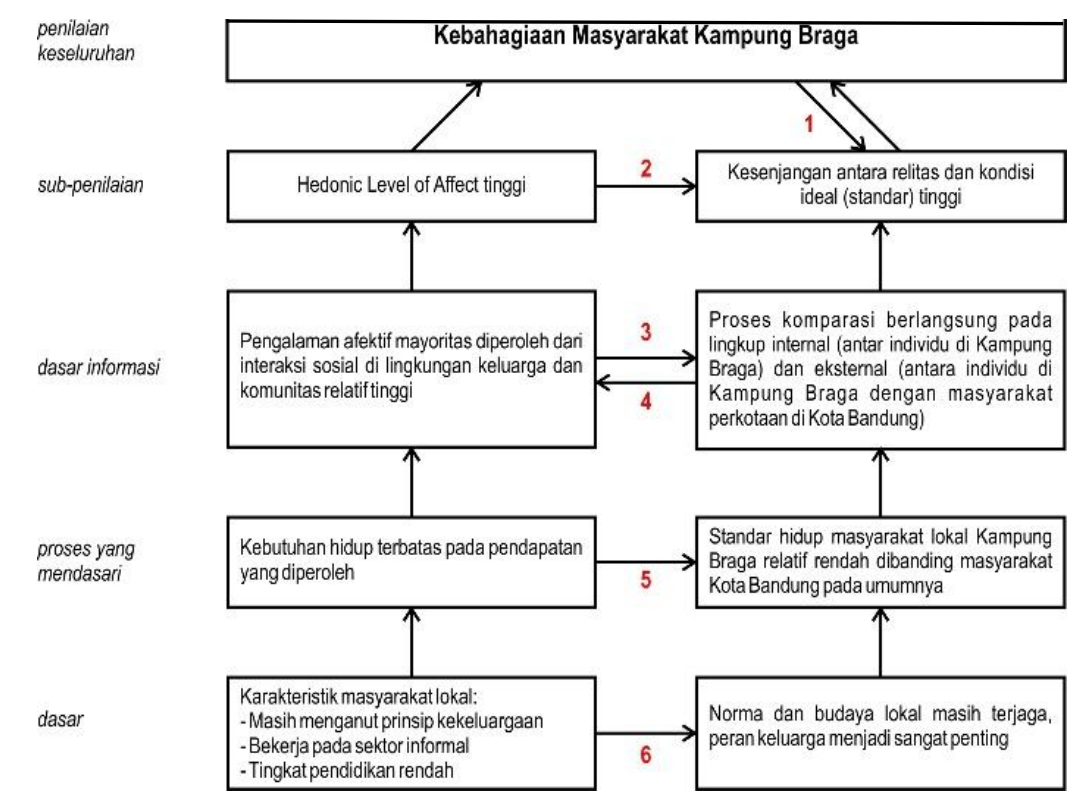

Sumber: Veenhoven, 2006 ; dimodifikasi

\section{Gambar 5. Proses Pembentukan Kebahagiaan Masyarakat Kampung Braga}

Meskipun demikian, setelah dilakukan penilaian agregat terkait tingkat kebahagiaan masyarakat, ternyata nilainya menunjukkan angka yang relatif tinggi, yaitu 0,978. Pada kasus ini, perlu diingat bahwa dalam pembentukan kebahagiaan masyarakat komponen hedonic level of affect memiliki peran yang signifikan, khususnya pada tingkat agregat. Tingginya hedonic level of affect pada lingkup agregat membuat kesenjangan antara realitas dan standar terlihat sempit. Hal tersebut dinamaan sebagai top-down effect, adapun pada Gambar 4.13 ditunjukkan oleh panah nomor (1). Panah nomor (2) menujukkan adanya peran hedonic level of affect terhadap contentment. 


\section{KESIMPULAN}

Berdasarkan temuan yang didapatkan, maka dapat disimpulkan bahwa tingkat kebahagiaan masyarakat kampung Braga berada pada tingkat sangat bahagia dengan nilai indeks kebahagiaan 0,978. Pada proses pembentukan kebahagiaan, komponen kognitif memiliki kontribusi sebesar 53,31\%, sedangkan komponen afektif sebesar 46,67\%. Variabel pemerintahan memiliki kontribusi tertinggi dalam pembentukan kebahagiaan masyarakat Kmapung Braga. Hal tersebut sejalan dengan yang diungkapkan oleh Layard (2005), bahwa tingkat kebahagiaan di banyak negara dipengaruhi oleh kualitas dari kinerja pemerintahnya. Adapun variabel Peran komunitas dan keluarga memiliki peran yang paling kecil dalam pembentukan indeks kebahagiaan masyarakat Kampung Braga. Hal tersebut disebabkan oleh kurangnya intensitas masyarakat Kampung Braga untuk dapat berekreasi. Terbatasnya ruang publik secara tidak langsung juga menjadi salah satu faktornya. Interaksi sosial hampir tidak dapat dilakukan di ruang publik. Faktor lainnya adalah banyaknya pendatang baru yang tinggal di Kampung Braga karena alasan pekerjaan. Mayoritas diantaranya jarang berinteraksi dengan tetangga dan kerabat di lingkungan tempat tinggalnya.

Pada akhirnya, penialian tingkat kebahagiaan masyarakat Kampung Braga ini membuktikan fenomena sosial perkotaan, bahwa perilaku masyarakat bergantung kepada ruang yang ditempatinya. Seperti yang diutarakan Leyden (2011) bahwa ruang kota memiliki peranan penting dalam memfasilitasi hubungan sosial masyarakat, tingkat kebahagiaan masyarakat Kampung Braga yang ternyata memiliki keterkaitan dengan tipologi kawasan tertentu. Kemampuan beradaptasi masyarakat Kampung Braga dengan lingkungan perkotaan membuat masyarakat kampung kota tidak hidup sebagaimana masyarakat urban lainnya. Jika selama ini masyarakat yang tinggal di ruang-ruang sempit kota dilihat sebagai masyarakat miskin yang merusak citra dan keindahan kota, tetapi pada satu sisi mereka merupakan aset dan identitas perkembangan permukiman di Kota Bandung. Prinsip kekeluargaan di kalangan masyarakat masih erat. Apabila dikaitkan dengan faktor lokasi, Kampung Braga berada pada wilayah strategis yang menghubungkan aktivitas perdagangan dan jasa di sekitarnya. Oleh karena itu, kebijakan Kota Bandung tidak hanya melihat pada pembangunan sarana prasarana perkotaan, tetapi juga perlu melihat lebih dalam pada kondisi masyarakat yang berada di ruang-ruang sempit kampung kota. Berdasarkan hal tersebut, perlu dikaji lebih dalam terkait tingkat kebahagiaan yang ada di kampung kota lainnya di Kota Bandung. Penelitian indeks kebahagiaan juga kedepannya dapat mengikutsertakan anak-anak sebagai objek penelitian. Metode penilaian tingkat kebahagiaan yang bervariasi, seperti metode Happy Planet Index, World Happiness, dan lain sebagainya, dapat menjadi metode baru untuk penelitian lanjutan.

\section{DAFTAR PUSTAKA}

Alkire, S. (2012). An Extensive Analysis of Gross National Happiness Index. Thimpu, Bhutan: The Centre for Bhutan Stdies. Retrieved from www.grossnationalhappiness.com

BPS Kota Bandung. (2015). Kota Bandung Dalam Angka 2015, 350.

Dwi, W., Agus, D., \& Dayana, I. (2016). Figuring the happiness of poor communities in Malang City : measuring the outcome of slum and squatter areas, 227(November 2015), 521-529. https://doi.org/10.1016/j.sbspro.2016.06.110

Goldberg, A., Leyden, K. M., \& Scotto, T. J. (2012). Untangling what makes cities liveable: happiness in five cities. Proceedings of the Institution of Civil Engineers - Urban Design and Planning, 165(3), 127-136. https://doi.org/10.1680/udap.11.00031

Layard, R. (2005). Happiness: lessons from a new science. Penguin Press. Retrieved from https://books.google.co.id/books/about/Happiness.html?id=nesQAQAAIAAJ\&redir_esc=y

Leyden, K. M., Goldberg, A., \& Michelbach, P. (2011). Urban Affairs Review, (April). https://doi.org/10.1177/1078087411403120

Lyubomirsky, S., King, L., \& Diener, E. (2005). The Benefits of Frequent Positive Affect : Does Happiness Lead to Success?, 131(6), 803-855. https://doi.org/10.1037/0033-2909.131.6.803 
Mroczek, D. K., \& Kolarz, C. M. (1998). The Effect of Age on Positive and Negative Affect : A Developmental Perspective on Happiness, 75(5), 1333-1349.

Okulicz-Kozaryn, A. (2017). Unhappy metropolis (when American city is too big). Cities, 61, 144-155. https://doi.org/10.1016/j.cities.2016.04.011

Pankaj, P., \& Dorji, T. (2012). Measuring Individual Happiness in Relation to Gross National Happiness in Bhutan. Stutzer, A., \& Frey, B. S. (2006). Does marriage make people happy , or do happy people get married ?, 35, 326347. https://doi.org/10.1016/j.socec.2005.11.043

Veenhoven, R. (1984). Conditions of happiness (1st ed.). Netherland: D. Reidel.

Veenhoven, R. (2000). Ordering concepts and measures of the good life. Journal Of Happiness Studies, 1(2000), 1-39. https://doi.org/10.1007/978-94-007-5702-8

Veenhoven, R. (2006). How do we assess how happy we are? Tenets, implications and tenability of three theories. Happiness, Economics and Politics: Towards a Multi-Disciplinary Approach, (October), 45-69. https://doi.org/http://www2.eur.nl/fsw/research/veenhoven/Pub2000s/2009a-full.pdf 